\title{
A Simple Survey on Attitude of Computer Science Diploma Students towards STEM
}

\author{
Azniah Ismail $^{1 *}$, Nor Zuhaidah Mohamed Zain ${ }^{1}$, Harnani Mat Zin ${ }^{1}$ \\ ${ }^{1}$ Computing Department, Faculty of Arts, Computing and Creative Industry, Universiti \\ Pendidikan Sultan Idris
}

Article History
Received:
17.09.2019
Revised:
26.10 .2019
Accepted:
19.11 .2019
*Corresponding Author:
Azniah Ismail
Email:
azniah@fskik.upsi.edu.my

Abstract: This article reported a simple survey on diploma students' attitudes towards science, technology, engineering, and mathematics (STEM) objectively to get an initial impression of students taking a STEM-related diploma program. The targeted respondents were diploma students pursuing computer science programs in a Malaysian public university. A quantitative approach using a quantitative survey was used in which data were systematically elicited from 16 male and 17 female students using a questionnaire containing Likert-scale items. The questionnaire consists of three constructs: attitude toward science, attitude toward technology and engineering, and attitude toward mathematics. All constructs use a 5-point Likert scale for the response scale. Descriptive analysis showed that the respondents' attitude ranged between moderately to highly positive towards STEM with no significance different variation between genders across the STEM fields. Interestingly, they also had, generally, moderate consideration for careers in STEM fields (the average values ranged between $27.2 \%$ and $42.4 \%$ ) with male respondents had very low agreements $(18.7 \%)$ to consider careers related to technology and engineering fields. Such results were a bit discouraging as the respondents were all pursuing a diploma in computer science.Thus, more efforts are needed by the university to give more exposures and experiences to refine the students' attitude during their study, to boost their confidence and interest to pursue a career suitable with their diploma certificates.

Keyword: STEM, Attitude, Computer Science, Diploma Students. 


\section{Introduction}

STEM simply refers to the academic disciplines of science, technology, engineering, and mathematics. The term is frequently used in many countries, including the United States and Malaysia. Similar acronyms are used in some other countries, such as MINT (Mathematik, Informatik, Naturwissenschaft und Technik) in Germany, and STGM (sciences, technologies, génie et mathématiques) in the French part of Canada [1].

According to White [2], the term STEM was first introduced almost two decades ago, but the concept was not new at that time. For example, STEM education had already flourished after the World War II and after the launching of Sputnik. Many countries who are keeping pace with technological or engineering developments and innovations, either to strengthen the economy as well as to protect from threats of other countries, or to remain or become leaders in the rapidly changing and expanding global economy, have taken steps to enrich and improve the STEM curriculum, STEM educational policy and STEM-related workforce development [3]. Hence, numerous STEM-related researches can be found focusing either on teachers [4], [5], [6], [7], [8] or students, in which the latter commonly involved school students [1], [9], [10], [11] and college or university students [12], [13], [14], [15].

Despite the urgent needs of well-built nations in STEM, Ali \& Shubra [24] have noted a declining level of interest towards STEM among many school leavers. A similar situation also happened in Malaysia [17]. Thus, it is not surprising to find many researchers discussed heavily on academic preparedness and students' interest in STEM [18], as well as other supporting factors such as STEM competitions [8], out-of-school STEM activities [19], [20] STEM pre-knowledge [1] and other STEM-based programs [11], [21] which highly likely encourage the students' pursuit of STEM fields in college.

Some researches were also carried out to investigate students' or youth's attitude towards STEM fields [10], [14], [22], Most of them reported moderately to highly positive attitudes. Moreover, there were also researchers that relate the attitude or interest with specific gender, such as Sahin et al. [15] who found that males were more likely to choose a STEM major in college than females, which contradicted with Mau et al. [13] who found that female students were more likely than male students to major in STEM field of studies. Simon et al [16] discussed more astonishing details when they relate gender with femininity and masculinity. Nonetheless, Whelan [23] and Heaverlo [9] decided to focus their research on females only.

In this study, we only focused on unfolding the attitude of students who were pursuing STEMrelated diploma program. We also interested to look at any possible variation of attitude between genders. In addition, we also look briefly into these students' consideration for careers in STEM fields. As such, this study was carried out involving a group of Malaysian diploma students pursuing computer science program at one of Malaysian public universities.

\section{Previous Work}

In this section, we presented some previous work's research designs and findings that mostly focused on the attitude towards STEM among school, college and university students. We summarized them in Table 1 . The following works reported moderately to highly positive attitudes towards STEM:

\section{$X u$ and Lewis}

$\mathrm{Xu}$ and Lewis [22] evaluated attitude towards the chemistry inventory subject among first year, university students through a quantitative survey. They had learned from the study that the students' attitudes were generally positive towards the subject. However, they did not discuss about the attitude thoroughly. Interestingly, they evaluated on attitude-achievement and ability-achievement basis, instead.

Their work was divided into two phases of evaluation. The first phase was more about building and refining their survey instrument based on 914 responses they received from students taking the general chemistry laboratory I and II courses at one of universities in the United State. With the revised version of their instrument, they conducted the second phase of evaluation. It has eight pairs of objectives to tap students' attitudinal status toward chemistry in general which have been organized in two subscales i.e. "intellectual accessibility" (items easy-hard, simple-complicated, clearconfusing, unchallenging-challenging) and "emotional satisfaction" (items satisfying-frustrating, pleasant-unpleasant, comfortable-uncomfortable, organized-chaotic). Both versions used a 7-point 
Likert scale. Students were instructed to answer according to their feelings toward chemistry field in general, not toward a teacher or a course.

The refined (second) version of instrument was given to 354 participants attending general chemistry I discussion sections during the 11th lecture week at the same institution. The data were then used to predict the students' achievement in general chemistry (ACS) using multiple regression analysis as captured by ACS exam scores. Three different regression models were tested. Initially, they used three predictors i.e. emotional satisfaction, intellectual accessibility and high school exams (SAT or ACT) scores as students' ability (before extended to include SAT, ACT and ACS scores individually). The results showed that the correlation between all five variables was classified as moderate. There was low correlation between attitude toward chemistry and mathematical ability measured on standardized tests (either SAT or ACT). The correlation between attitude-achievement was consistent with extensive studies and not as strong as the ability-achievement correlation.

$\mathrm{Xu}$ and Lewis [22] also mentioned that it is normal for: (i) low correlation between attitude toward chemistry and mathematical ability because they are conceptually distinct, (ii) high correlation between two components of the same concept of attitude (i.e., cognition and emotion) because they are related but not identical, and (iii) highest correlation between SAT and Act scores because both intended to measure mathematics ability and used for the college admission. Xu and Lewis [22] concluded with students' attitudes played a significant role in predicting final achievement in a general chemistry course even when initial ability scores were considered.

\section{Faber et al.}

Faber et al. [10] reports on the development of instruments for measuring:

1. students' attitudes towards STEM subjects,

2. students' interest in STEM careers, and

3. 21st century skills among school children. The development was being carried out by a team of researchers at The Friday Institute for Educational Innovation at North Carolina State University. They focused on developing a systematic instrument that is suitable for young students (the upper elementary school and middle or high school students) across all STEM fields.

Each version of the survey contained four, validated constructs which use Likert-scale items. The surveys have been administered to over 10,000 fourth through twelfth grade students in North Carolina. The instrument development process was divided into four major survey administration events:

1. development of the pilot survey,

2. pilot administration

3. middle or high school survey,

4. upper elementary school survey, and

5. final survey.

During the early development, the team looked for existing instrument and found 47-items instrument which was designed to measure student attitudes toward STEM and interest in STEMrelated careers for middle school girls. It consists of three scales i.e. attitudes towards engineering, attitudes towards math, and attitudes towards science. The instrument used a 5-point Likert scale for the response scale. The team also added a fourth scale that measure student attitudes towards $21 \mathrm{st}$ century skills to meet other goals of their project grants. The 7-items scale was adapted from a comprehensive 38-items student learning conditions survey commissioned by the governor of North Carolina and developed by the Friday Institute in 2010. It was slightly modified to become a 5-point Likert scale items, and another nine items were added from the Friday Institute's original pilot 21st century skills scale. Slight changes were also done onto the items' statements to suit their respondents. Finally, the research team added a "Your Future" section to the survey to measure student interest in STEM career pathways. Starting with the list of 12 STEM careers the team came up with a list of 43 STEM careers based on the Bureau of Labor Statistics' Occupational Outlook Handbook. This section used 4-point Likert scale.

The research team then administered the pilot survey 109 6th to 12th graders who were participating in various programs within the NSF-funded outreach project. They conducted factor 
analysis to make sure the construct validity. They also performed content validity analyses with three subject matter experts. Based on the findings, further changes were done on the instrument. Some items were revised or dropped, and career items were edited down back to 12 items. The refined survey tool was known as S-STEM.

The research team administered the S-STEM to 9,081 6th to 12th grade students (middle or high school). They also used the S-STEM to create a version for 4th to 5th grade (upper elementary school) and further refined it through some cognitive interviews with the 5th-graders. From there, they administered upper elementary S-STEM to 799 4th to 5th students. They used the findings to assess construct validity, calculate reliability of each construct, revise to retain parallelism of instruments, assess reading level and analyse function with gender groups. Seven middle and high school teachers and ten upper elementary school teachers confirmed that their respective S-STEM survey tools were at an appropriate length and difficulty for their students. With the finalized S-STEM survey tool, the development was completed. By going through their many surveys, Faber et al. [10] summarized some baseline findings:

1. students' attitudes toward STEM subjects were moderately positive with slight variation in attitude between students at different school-levels,

2. the students' interest in STEM careers were also moderate but female students had particularly low levels of interest in engineering, computer science, energy, and physics careers,

3. all students highly favoured 21 st century skills.

\section{Popa and Ciascai}

The Popa and Ciascai's [14] work is an example of applied research using the attitude measurement tools reported in Faber et al. [10] above. Popa and Ciascai [14] conducted a survey to investigate the opinion of 110 students of different STEM field programs, different study program level (bachelor, master and doctorate) and from different universities across Romania towards STEM.

Popa and Ciascai [14] focused on several factors including:

1. the students' experience in STEM fields during their high school,

2. profession

3. skills related to engineering, and

4. the factors that influenced their decision to pursue degree in STEM fields.

They slightly modified the original questionnaire to suit their research objectives. The first and second parts of questionnaire used a 5-point Likert scale, the third part used a 4-point Likert scale (without neutral category), and the fourth part only requires 3-point Likert scale (that consists only of yes, no and I don't know). The questionnaire was administered online using Google Forms. The questionnaire was first sent to students in the Faculty of Chemistry and Chemical Engineering in one university with a written request to share it with students from other faculties and universities in Romania. 110 students from different faculties and different universities had responded voluntarily to join the study.

Popa and Ciascai's [14] findings showed that their respondents had been interested in STEM fields since their schooldays, which had encouraged them to continue their studies in the STEM field. Popa and Ciascai [14] did mentioned about Romania having a more developed curriculum in sciences compared to humanities. The high school students studied mathematics, chemistry, physics and biology about 6 to 11 hours per week. Chemistry receives the highest number of responses showing great interest followed by medicine, then engineering. In general, more than $80 \%$ respondents have great interest in chemistry and almost $70 \%$ of them actually continue taking chemistry at university level. On the other hand, the number of responses that saying they are currently studying medicine at university level was very low despite of great interest towards medicine field. This scenario is highly likely caused by tough admission requirements.

According to Popa and Ciascai [14], a high number of responses for positive experience with mathematics and science during schooldays was also seen to be consistent with previous studies that linked the positive experience with high number of people choosing STEM fields. Teachers who taught the students STEM related subjects also become one of the factors that strongly influenced the students in choosing their program studies. They were also convinced of the importance of engineer profession, engineering knowledge and skills. Popa and Ciascai [14] also emphasized that there was 
no question about gender difference when it comes to STEM education in Romania. More than half responses in their study came from female students.

Table 1. Comparison among Previous Works Related To Attitude towards STEM

\begin{tabular}{|c|c|c|c|}
\hline Researcher & Research Design & Their Findings & Review Note \\
\hline $\mathrm{Xu} \&$ Lewis [22] & $\begin{array}{lrr}\text { Type: Quantitative } & \text { survey } \\
\text { Instrument: } & \text { 8-item } \\
\text { questionnaires } & & \text { (final } \\
\text { version) } & & \\
\text { Participant: } & 914 & \text { (first } \\
\text { dministration) } & \text { and } & 354 \\
\text { (second } & \text { administration) } \\
\text { first-year, } & & \text { university } \\
\text { students } & & \end{array}$ & $\begin{array}{l}\text { Students' attitudes played a } \\
\text { significant role in predicting } \\
\text { final achievement in a } \\
\text { general chemistry course } \\
\text { even when initial ability } \\
\text { scores were considered. } \\
\text { However, it is not as stronger } \\
\text { as the ability scores. }\end{array}$ & $\begin{array}{l}\text { Include interesting discussion } \\
\text { about strong ability-achievement } \\
\text { relationship and they relate it to } \\
\text { college admission decision in the } \\
\text { U.S. that often consider SAT or } \\
\text { ACT scores as an indication of } \\
\text { students' ability. Their findings } \\
\text { may help ease the long debate } \\
\text { among education stakeholders } \\
\text { regarding how to interpret test } \\
\text { scores and create education } \\
\text { policy. However, we did not get } \\
\text { an access to their instrument. }\end{array}$ \\
\hline Faber et al. [10] & $\begin{array}{l}\text { Type: Quantitative survey } \\
\text { Instrument: } \quad 52 \text {-item } \\
\text { questionnaire for } \\
\text { middle/high, 26-item } \\
\text { questionnaire for upper } \\
\text { elementary } \\
\text { Participant: } \\
109 \text { middle/high school } \\
\text { students (first phase), } \\
9081 \text { middle/high school } \\
\text { students (second phase) } \\
799 \text { upper elementary school } \\
\text { students. }\end{array}$ & $\begin{array}{l}\text { Students' attitudes toward } \\
\text { STEM subjects were } \\
\text { moderately positive with } \\
\text { slight variation in attitude } \\
\text { between students at different } \\
\text { school-levels. }\end{array}$ & $\begin{array}{l}\text { A thorough and detailed } \\
\text { explanation of the attitude } \\
\text { measurement tool development } \\
\text { process with finalized survey } \\
\text { tools are both included in the } \\
\text { paper. }\end{array}$ \\
\hline Popa \& Ciascai [14] & $\begin{array}{l}\text { Type: Quantitative survey } \\
\text { Instrument: } \\
\text { Participant: } 110 \text { Romanian } \\
\text { university students }\end{array}$ & $\begin{array}{l}\text { Most responses from students } \\
\text { at all university level } \\
\text { indicating their attitude } \\
\text { towards STEM were highly } \\
\text { positive. The findings also } \\
\text { showed that the students had } \\
\text { been interested in STEM } \\
\text { fields since their school days, } \\
\text { which had encouraged them } \\
\text { to continue their studies in the } \\
\text { STEM field. Teachers who } \\
\text { taught the students STEM } \\
\text { related subjects have become } \\
\text { one of the factors that } \\
\text { strongly influenced them in } \\
\text { choosing their program } \\
\text { studies. }\end{array}$ & $\begin{array}{l}\text { Popa and Ciascai mentioned } \\
\text { about no gender differences with } \\
\text { more than } 69 \% \text { respondent were } \\
\text { female. Further study might be } \\
\text { required to study the ratio of } \\
\text { male students to female students } \\
\text { at the university level. It is also } \\
\text { good to know that Romania has } \\
\text { implemented strong curriculum } \\
\text { for science at school level. }\end{array}$ \\
\hline
\end{tabular}

\section{Materials and Method}

\subsection{Sample of Study}

The sample of our study consisted of 33 second year diploma students of Computer Science program during the 2017/2018 academic session.

\subsection{Research Method}

The study was conducted during the end of 2017/2018 short semester session. The research method was divided into four phases as follows:

- Planning - the objectives and hypothesis were formulated. Some existing and validated questionnaires were obtained and grinded. We chose items suitable for our research and built our questionnaire. 
- Collecting data - the questionnaire was distributed among second year diploma students and collected back after a week.

- Analysis - appropriate statistical techniques were conducted to analyze the survey data.

- Discussion - analysis results were discussed.

\subsection{Research Instrument}

We found a validated survey by Faber et al. [10] that sought to measure a similar set of student attitudes and we used portions of the instrument in our study. Our questionnaire consists of four main parts. The first part (having 5 items) used to elicit information regarding respondents' demographics (namely age, gender, and academic background), their previous high school results and their future planning to further study after pursuing the Diploma.

The second part (having 8 items) used to collect information pertaining to attitude towards science. The third and fourth parts (having 8 items each) used to collect information about attitude towards technology and engineering, and mathematics, respectively. See Table 2 for measured items for each STEM field. In our study, the constructs were measured, to which the respondents were required to indicate the level of their agreements along a 5-point Likert's type scale using the following anchors: (1) Strongly disagree, (2) Disagree, (3) Neutral, (4) Agree, and (5) Strongly agree.

Table 2. STEM Fields and the Measured Items

\begin{tabular}{|c|c|}
\hline Field & Measured item \\
\hline Science & $\begin{array}{l}\text { B1 - I know I can do well in science. } \\
\text { B2 - I am sure of myself when I do science. } \\
\text { B3 - I will need science for my future work. } \\
\text { B4 - I expect to use science when I get out of school. } \\
\text { B5 - Knowing science will help me earn a living. } \\
\text { B6 - I would consider a career in science. } \\
\text { B7 -I can handle most subjects well, but I cannot do a good job with } \\
\quad \text { science. } \\
\text { B8 - I am sure I could do advanced work in science. }\end{array}$ \\
\hline $\begin{array}{l}\text { Technology \& } \\
\text { Engineering }\end{array}$ & $\begin{array}{l}\text { C1 - I am good at building and fixing things. } \\
\text { C2 - I like to imagine creating new products. } \\
\text { C3 - I am interested in what makes machine work. } \\
\text { C4 - I am curious about how electronics work. } \\
\text { C5 -If I learn engineering, then I can improve things that people use } \\
\text { everyday } \\
\text { C6 - Knowing how to use math and science together will allow me to invent } \\
\text { useful things. } \\
\text { C7 - Designing products or structures will be important for my future work. } \\
\text { C8 - I believe I can be successful in a career in engineering. }\end{array}$ \\
\hline Mathematics & $\begin{array}{l}\text { D1 - I am the type of student to do well in mathematics. } \\
\text { D2 - I am good at mathematics. } \\
\text { D3 - I can get good grades in mathematics. } \\
\text { D4 - Mathematics is hard for me. } \\
\text { D5 - Mathematics has been my worst subject. } \\
\text { D6 - I can handle most subjects well, but I cannot do a good job with } \\
\text { mathematics. } \\
\text { D7 - I would consider choosing a career that uses mathematics. } \\
\text { D8 - I am sure I could do advanced work in mathematics. }\end{array}$ \\
\hline
\end{tabular}

Adapted from Faber et al., [10]

\subsection{Statistical Analysis}

Once data were successfully collected, the responses were recorded onto a spreadsheet application and later analyzed using R (version 3.5). We used descriptive analysis to get the frequency count, sum and percentage. Kruskal-Wallis rank sum test was used to test whether there were different attitudes 
occur between genders. The test type was deemed appropriate because we had Likert data and Kruskal-Wallis rank sum test is a test on populations using median. We also chose Spearman's rank correlation coefficient to test correlations between Likert data. We were looking for strong positive and strong negative correlations between variables to understand a firm stand from the respondents about their attitude towards each STEM field.

Each section of the survey data was analysed separately, i.e. the science knowledge, the technology and engineering knowledge and the mathematics knowledge, and then the career-related data were analysed for each field before later analysed as one whole unit.

\section{Results and Discussion}

\subsection{Demographics of Respondents}

Descriptive analysis results in Table 3 showed the sample study was consists of 16 male and 17 female diploma students. 30 students were from science background and the remaining 3 students were from arts background. Their ages were mostly 19 years old and were not more than 21 years old. Table 3 summarizes the demographics of the respondents in this study.

Table 3. Summary of Academic Background, Age and Gender

\begin{tabular}{llllll}
\hline Gender & Background & \multicolumn{3}{c}{ Age } & Total \\
\cline { 3 - 5 } & & 19 & 20 & 21 & 16 \\
\hline \hline Male & Science & 11 & 2 & 1 & 17 \\
& Arts & 1 & 0 & 1 & 17 \\
Female & Science & 16 & 0 & 0 & 33 \\
& Arts & 1 & 0 & 0 & 2 \\
\hline Total & & 29 & 2 &
\end{tabular}

Note. All the respondents were from the same institution [Universiti Pendidikan Sultan Idris], who were in their second year taking the same diploma program [Diploma in Computer Science]

\subsection{Respondents' Attitude towards Science}

The respondents' responses to the second part of the questionnaire were analyzed to measure their attitude towards science. A stacked bar chart is used to represent the results in general (see Figure 1). Analysis results showed that the respondents had a moderate attitude towards science. The greatest proportion of respondents indicated that they were "strongly agree" or "agree" knowing science will help them earn a living $(66.6 \%)$ and followed by "I will need science for my future work $(51.5 \%)$ but they moderately expected to use science when they get out of school (42.4\%). Another moderate proportion of respondents also indicated that they were "strongly agree" or "agree" they can do well in science (33.3\%) and "I am sure of myself when I do science" (30.3\%). Meanwhile, only $18 \%$ of the respondents were "strongly disagree" and "disagree" that they cannot do a good job in science. We made sure only positive statement variables were left to measure the attitude using median. The median values for all variables ranged between 3 and 4 with mostly were 3 .

We had expected to see negative correlation between "I know I can do well in science" and "I can handle most subjects well, but I cannot do a good job with science" $(\mathrm{r}=-.61, \mathrm{p}>.001)$ and positive correlation between "I will need science for my future work" and "I expect to use science when I get out of school" $(\mathrm{r}=.40, \mathrm{p}=.001)$. These results showed that the respondents were firm about their moderate attitude towards science.

To determine any significant difference of respondents' attitude towards science between genders using Kruskal-Wallis rank sum test, we set our null hypothesis to be "the population medians are all equal". At .05 significance level, the attitude towards science between gender are identical (between $p$ $=.50$ and $\mathrm{p}=.96$ ). Thus, we conclude that computer science diploma students' attitude toward science was moderately positive with no significance different variation between gender. 


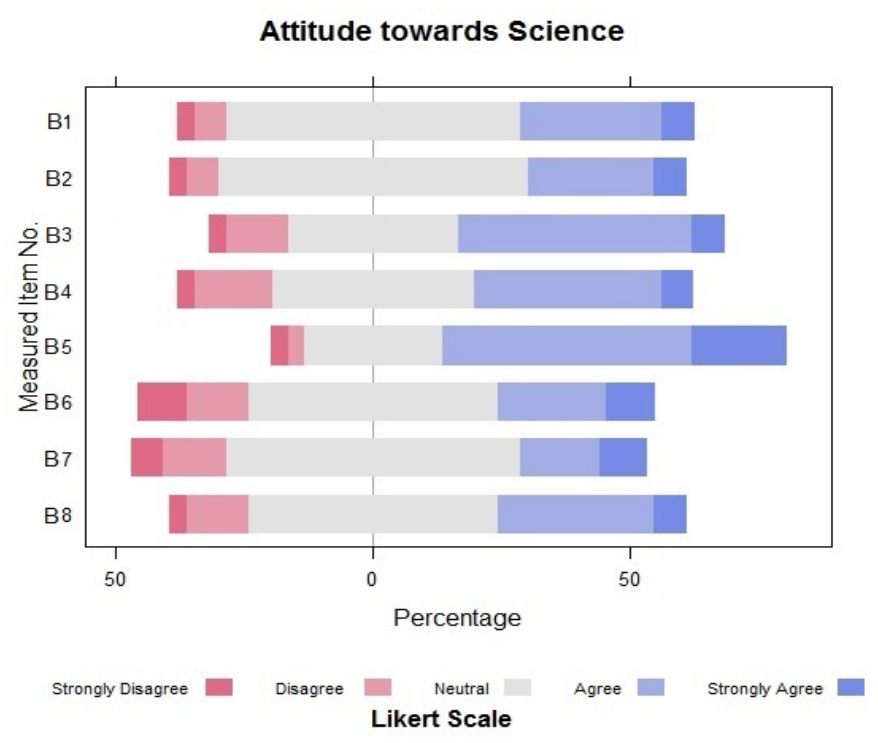

Figure 1. A Stacked Bar Chart Showing Results for the Science Section of the Survey

\subsection{Respondents' Attitude towards Technology and Engineering}

The respondents' responses to the third part of the questionnaire were analyzed to measure their attitude towards technology and engineering. Another stacked bar chart is used to represent the results in general (see Figure 2). Analysis results showed that the respondents had quite high attitude towards technology and engineering. The median values for all variables ranged between 3 and 4 with mostly were 4 . There was no negative statement variable to be removed before analyzing the median.

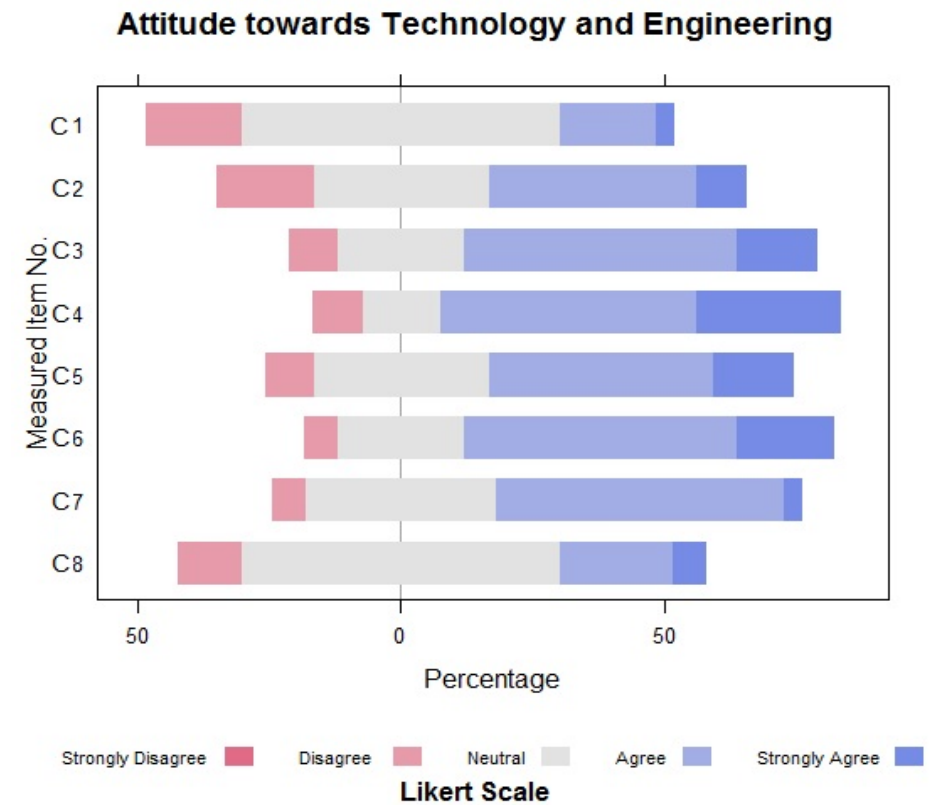

Figure 2. A Stacked Bar Chart Showing Results For the Technology and Engineering Section of the Survey

The largest proportion of respondents indicated that they were "strongly agree" or "agree" had curiosity about how electronics work (75.7\%), followed by "knowing how to use math and science together will allow me to invent useful things" $(69.6 \%)$ and "I am interested in what makes machine work" $(66.6 \%)$. Similar large proportions of respondents agreed that "designing products or structures 
will be important for my future work (57.5\%) and "if I learn engineering, then I can improve things that people use every day" (57.5\%). Astonishingly, a very small proportion of respondents agreed that they were good at building and fixing things $(21.2 \%)$.

Again, to determine any significant differences between the students' attitude towards technology and engineering between gender, we used Kruskal-Wallis rank sum test with similar null hypothesis. We conclude that attitude towards the technology and engineering between gender are identical (between $\mathrm{p}=.19$ and $\mathrm{p}=.93$ ) at .05 significance level. In addition, there were strong positive correlation between "I am interested in what makes machine work" and "I am curious about how electronics work" ( $\mathrm{r}=.80, \mathrm{p}>.001)$, and between "I am interested in what makes machine work" and "if I learn engineering, then I can improve things that people use every day" $(r=.64, p>.001)$.

The students' attitude towards technology and engineering was a bit interesting. The respondents showed high curiosity and interest towards technology and engineering. They also agreed that designing products will be important for their work in future, only that they have low confidence in building and fixing things. Thus, we conclude that computer science diploma students' attitude toward science was quite highly positive with no significance different variation between gender. Nonetheless, improvements were needed to boost the students' confidence in technology and engineering.

\subsection{Respondents' Attitude towards Mathematics}

Another stacked bar chart is used to represent the results for mathematic section of the survey in general (see Figure 3).

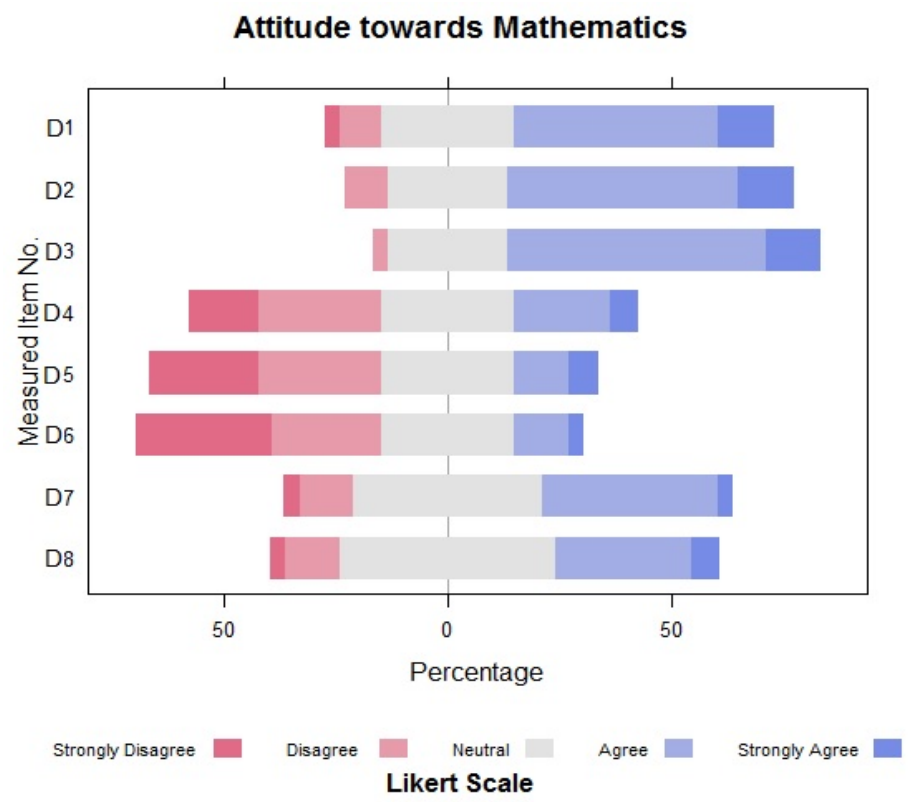

Figure 3. A Stacked Bar Chart Showing Results For the Mathematic Section of the Survey

Analysis results showed that the respondents had generally claimed that they were quite good in mathematics. The greatest proportion of respondents indicated that they were "strongly agree" or "agree" they can get good grades for the subject (69.6\%), followed by "I am good at mathematics" (63.6\%) and "I am the type of student to do well in mathematics" (57.5\%). At the other hand, the proportion of respondents became smaller when indicating that they were "strongly agree" and "agree" that "I can handle most subjects well, but I cannot do a good job with mathematics" $(15.1 \%)$, followed by "mathematics has been my worst subject" (18.1\%) and "math is hard for me" $(27.2 \%)$. Again, we made sure only positive statement variables were left to measure the attitude using median. The median values for all variables ranged between 3 and 4 with mostly were 4 . 
In addition, there were strong positive correlations of responses about the three D1, D2 and D3 statements as shown in Figure 4. The results indicated that those respondents who agreed they can do well in Mathematics also agreed they good at mathematics and agreed they can get good grades, whereas those who did not agree they can do well also did not agree that they good at mathematics and did not agree they can get good grades (between $\mathrm{r}=.92$ and $\mathrm{r}=.84, \mathrm{p}>.001$ ). Another strong positive correlations were also seen among the three D4, D5 and D6 statements: between "Math has been my worst subject" and "I can handle most subjects well, but cannot do a good job with mathematics" ( $\mathrm{r}=.90, \mathrm{p}>.001)$, between "Mathematics is hard for me" and "I can handle most subjects well, but cannot do a good job with mathematics" $(\mathrm{r}=.84, \mathrm{p}>.001)$, and between "Mathematics is hard for me" and "Math has been my worst subject" $(r=.74, p>.001)$.

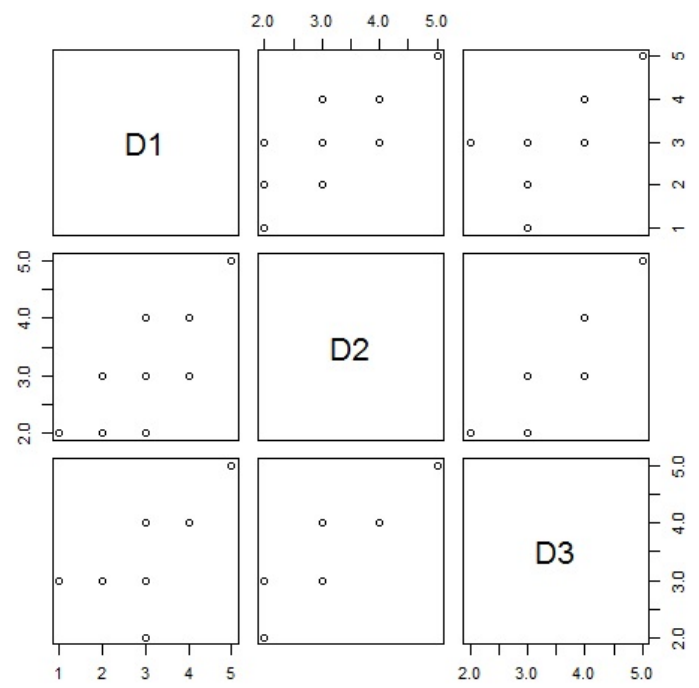

Figure 4. Positive Correlations of Responses for D1, D2 and D3 in Mathematics Section

Moreover, as expected, some strong negative correlations occurred between the followings: "I am the type of students to do well in mathematics" and "Math is hard for me" $(r=-.72, p<.001)$, "I can get good grades in mathematics" and "mathematics has been my worst subject" $(r=-.62, p<.001)$. These findings showed that the respondents' responses were firm.

Again, to determine any significant differences between the respondents' capability towards mathematics between gender we used Kruskal-Wallis rank sum test with similar null hypothesis. The results showed that attitude towards mathematics between gender are identical (between $p=.20$ and $p$ $=.98)$ at .05 significance level. In general, we conclude that computer science diploma students' attitude was quite highly positive towards mathematics with no significance different variation between genders.

\subsection{Consideration for Careers in STEM Fields}

Analysis results as in Table 4 showed that computer science diploma students had generally moderate consideration for careers in STEM fields. All median values for considering a career in each STEM field were 3 only.

The greatest proportion of respondents indicated that they were "strongly agree" or "agree" to consider careers that uses mathematics $(42.4 \%)$, while the smallest proportion of respondents reported that they were "strongly agree" or "agree" to consider careers in technology and engineering related field (27.2\%). On average, female and male respondents expressed a similar level of consideration for careers in STEM fields (37.5\% and $31.9 \%$ on average) with female respondents had slightly higher agreement to consider careers that uses mathematics (47.0\%), and careers related to technology and engineering field (37.5\%), compared to male respondents who had lower agreement to consider careers related to mathematics field (37.5\%), and careers related to technology and engineering field 
(18.7\%). Such results were a bit discouraging as the respondents were all pursuing a diploma in computer science.

Table 4. Results on Considering Careers in the STEM Fields between Genders

\begin{tabular}{|c|c|c|c|c|}
\hline \multirow[b]{2}{*}{ Gender } & \multicolumn{4}{|c|}{ Science } \\
\hline & Frequency & $\%$ & Total & $\%$ \\
\hline Male & 5 & 31.2 & 10 & 30.3 \\
\hline \multirow[t]{2}{*}{ Female } & 5 & 29.4 & & \\
\hline & \multicolumn{4}{|c|}{ Technology \& Engineering } \\
\hline Gender & Frequency & $\%$ & Total & $\%$ \\
\hline Male & 3 & 18.7 & 9 & 27.2 \\
\hline \multirow[t]{2}{*}{ Female } & 6 & 37.5 & & \\
\hline & \multicolumn{4}{|c|}{ Mathematics } \\
\hline Gender & Frequency & $\%$ & Total & $\%$ \\
\hline Male & 6 & 37.5 & 14 & $\overline{42.4}$ \\
\hline \multirow[t]{2}{*}{ Female } & 8 & 47.0 & & \\
\hline & \multicolumn{4}{|c|}{ STEM (as a whole) } \\
\hline Gender & Average & $\%$ & Total (on average) & $\%$ \\
\hline Male & 5 & 31.2 & 11 & 33.3 \\
\hline Female & 6 & 37.5 & & \\
\hline
\end{tabular}

Note. Total number of respondents, $\mathrm{n}=33$

As some research indicates that greater confidence leads to greater interest and vice versa [25], we may link this shortcoming with students having low confidence in fixing and building things as discussed earlier. Most probably, the students were also having low STEM career knowledge, making them not well familiarized with related careers in the fields. Blotnicky et al. [1] study found that STEM career knowledge correlates with students' interest in pursuing careers involving STEM, thus suggested the exposure of students to STEM careers. In our case, is to give the students more exposure to computer science careers. Other suggestion taken from [8], is to encourage students to participate in science fairs, robotics competitions, computing contests and other STEM competitions.

\section{Conclusion}

In this study, we discuss the attitude of students taking computer science diploma towards STEM. No significant difference between male and female students' attitude towards STEM fields was reported. As demonstrated, students' capability in mathematics subjects seem to be quite strong but moderate in science (that could be correlated with their previous high school results which they used to get admission to the computer science program but were not discussed in this paper). Furthermore, they had high curiosity and interest about products of technology and engineering and realized that designing products will be important for their future work.

However, surprisingly, they had moderate consideration to have a career in STEM-related fields despite the facts that they were all pursuing a diploma in computer science. Clearly, they have shown some signs of low confidence as most of them disagreed that they were good at building and fixing things and disagreed that they believed they can be successful in a career related to technology and engineering. Hence, more efforts are needed by the University to give exposures and experiences in computer science field to the diploma students to boost their interests and confidence in the field, which in turn hopefully helps to refine the students' attitude. Nonetheless, our findings can be used to build an extended study on improving the attitude towards STEM and maintaining the interest in STEM-related career among the computer science diploma students.

\section{References}

[1] K. A. Blotnicky, T. Franz-Odendaal, F. French, and P. Joy, "A study of the correlation between STEM career knowledge, mathematics self-efficacy, career interests, and career activities on 
the likelihood of pursuing a STEM career among middle school students," International Journal of STEM Education, vol. 5, no. 1, pp. 22, 2018. [Online]. Available: https://doi.org/10.1186/s40594-018-0118-3. [Accessed: May 2019]

[2] D. W. White, "What is STEM education and why is it important?," Florida Association of Teacher Educators Journal, vol. 1, no. 14, pp. 1-9, 2014. [Online]. Available: https://doi.org/10.1136/bmj.322.7301.1536. [Accessed: June 2019]

[3] J. M. Ritz, and S. C. Fan, "STEM and technology education: international state-of-the-art," International Journal of Technology and Design Education, vol. 25, no. 4, pp. 429-451. [Online]. Available: https://doi.org/ 10.1007/s10798-014-9290-z. [Accessed: June 2019]

[4] M. Barak, "Closing the Gap between Attitudes and Perceptions about ICT-Enhanced Learning among Pre-service STEM Teachers," Journal of Science Education and Technology, vol. 23, no. 1, pp. 1-14, 2014. [Online]. Available: https://doi.org/10.1007/s10956-013-9446-8. [Accessed: June 2019]

[5] C. Kim, D. Kim, J. Yuan, R B. Hill, P. Doshi, and C. N. Thai, "Robotics to promote elementary education pre-service teachers' STEM engagement, learning, and teaching," Computers \& Education, vol. 91, pp. 14-31, 2015. [Online]. Available: https://doi.org/http://dx.doi.org/10.1016/j.compedu. 2015.08.005. [Accessed: May 2019]

[6] B. Thomas, and J. J. Watters, "Perspectives on Australian, Indian and Malaysian approaches to STEM education," International Journal of Educational Development, vol. 45, pp. 42-53, 2015. [Online]. Available: https://doi.org/10.1016/j.ijedudev.2015.08.002. [Accessed: June 2019]

[7] B. Tekerek, and F. Karakaya, "Stem Education Awareness of Pre-Service Science," International Online Journal of Education and Teaching (IOJET), vol. 5, no. 2, pp. 348-359, 2015.

[8] K. Miller, G. Sonnert, and P. Sadler, "The influence of students' participation in STEM competitions on their interest in STEM careers," International Journal of Science Education, Part B: Communication and Public Engagement, vol. 8, no. 2, pp. 95-114, 2018. [Online]. Available: https://doi.org/10.1080/ 21548455.2017.1397298. [Accessed: June 2019]

[9] C. A. Heaverlo, C. A, "STEM development: A study of 6th--12th grade girls' interest and confidence in mathematics and science," ProQuest Dissertations and Theses, vol. 142, 2011.

[10] M. Faber, A. Unfried, J. Corn, and L. W. Townsend, "Student Attitudes toward STEM: The Development of Upper Elementary School and Middle / High School Student Surveys," 120th ASEE Annual Conference \& Exposition, Paper ID \#6955, 2013. [Online]. Available: https://doi.org/10.1002/ sce.3730740605. [Accessed: June 2019]

[11] E. H. M. Shahali, L. Halim, M. S. Rasul, K. Osman, and N. Mohamad Arsad, "Students' interest towards STEM: a longitudinal study," Research in Science \& Technological Education, vol. 5143, pp. 1-19, 2018. [Online]. Available: https://doi.org/10.1080/02635143.2018. 1489789. [Accessed: May 2019]

[12] A. V. Maltese, C. S. Melki, and H. L. Wiebke, "The Nature of Experiences Responsible for the Generation and Maintenance of Interest in STEM," Science Education, vol. 98, no. 6, pp. 937962, 2014. [Online]. Available: https://doi.org/10.1002/sce.21132

[13] W. J. Mau, V. J. Perkins, and Y. Mau, "Gender and Racial Differences in Career Decisionmaking Dispositions of College Students Enrolled in STEM Majors," Universal Journal of Psychology, vol. 4, no. 6, pp. 254-260, 2016. [Online]. Available: https://doi.org/10.13189 /ujp.2016.040602. [Accessed: June 2019]

[14] R. -A. Popa, and L. Ciascai, "Students' attitude towards STEM education," Acta Didactica Napocensia, vol. 10, no. 4, pp. 55-62, 2017. [Online]. Available: https://eric.ed.gov/?id= EJ1164986. [Accessed: May 2019]

[15] A. Sahin, A. Ekmekci, and H. C. Waxman, "The relationships among high school STEM learning experiences, expectations, and mathematics and science efficacy and the likelihood of majoring in STEM in college," International Journal of Science Education, vol. 39, no. 11, pp. 1549-1572, 2017. [Online]. Available: https://doi.org/10.1080/09500693.2017.1341067. [Accessed: June 2019]

[16] R. M. Simon, A. Wagner, and B. Killion, "Gender and choosing a STEM major in college: Femininity, masculinity, chilly climate, and occupational values," Journal of Research in 
Science Teaching, vol. 54, no. 3, pp. 299-323, 2017. [Online]. Available: https://doi.org/10.1002/tea.21345. [Accessed: May 2019]

[17] L. Halim, and T. S. M. Meerah, "Science Education Research and Practice in Malaysia," in Science Education Research and Practice in Asia, Ed M. H. Chiu, Singapore: Springer, pp. 7193, 2016.

[18] X. Wang, "Why Students Choose STEM Majors: Motivation, High School Learning, and Postsecondary Context of Support," American Educational Research Journal, vol. 50, no. 5, pp. 1081-1121, 2013. [Online]. Available: https://doi.org/10.3102/0002831213488622. [Accessed: May 2019]

[19] F. Ozis, A. O. Pektas, M. Akca, and A. Devoss, "How to Shape Attitudes toward STEM Careers: The Search for the Most Impactful Extracurricular Clubs How to Shape Attitudes Toward STEM Careers : The Search for the Most Impactful Extracurricular Clubs," Journal of Pre-College Engineering Education Research (J-PEER), vol. 8, no. 1, 2018.

[20] J. Vennix, P. den Brok, and R. Taconis, "Do outreach activities in secondary STEM education motivate students and improve their attitudes towards STEM?," International Journal of Science Education, vol. 693, pp. 1-21, May 2018. [Online]. Available: https://doi.org/10.1080/09500693.2018.1473659. [Accessed: June 2019]

[21] K. H. Tseng, C. C. Chang, S. J. Lou, and W. P. Chen, "Attitudes towards science, technology, engineering and mathematics (STEM) in a project-based learning (PjBL) environment," International Journal of Technology and Design Education, vol. 23, no.1, pp. 87-102, 2013. [Online]. Available: https://doi.org/10.1007/s10798-011-9160-x. [Accessed: June 2019]

[22] X. Xu, and J. E. Lewis, "Refinement of a Chemistry Attitude Measure Supplementary Material for Refinement of a Chemistry Attitude Measure for College Students," Journal of Chemical Education, vol. 88, no. 5, pp. 561-568, 2011. [Online]. Available: https://doi.org/10.1021/ed900071q. [Accessed: June 2019]

[23] G. C. Whelan, Women in STEM at a California community college: a case study. California State University, 2017. [Online]. Available: https://search.proquest.com/docview/1950133407? pq-origsite=gscholar. [Accessed: May 2019]

[24] A. Ali, C. Shubra, "Efforts to reverse the trend of enrolment decline in computer science programs: issues in informing science and information," Technology 7, pp. 209-224, 2010.

[25] J. J. Denissen, N. R. Zarrett, and J. S. Eccles, "I like to do it, I"m able, and I know I am: Longitudinal couplings between domain-specific achievement, self-concept, and interest," Child Development, vol. 78, no. 2, pp. 430-447, 2007. 